\title{
Detection of Helicobacter pylori in City Water, Dental Units' Water, and Bottled Mineral Water in Isfahan, Iran
}

\author{
Ahmad Reza Bahrami, ${ }^{1}$ Ebrahim Rahimi, ${ }^{2}$ and Hajieh Ghasemian Safaei ${ }^{3}$ \\ ${ }^{1}$ Faculty of Veterinary Medicine, Islamic Azad University, Shahrekord Branch, Shahrekord, Iran \\ ${ }^{2}$ Department of Food Hygiene, Faculty of Veterinary Medicine, Islamic Azad University, Shahrekord Branch, Shahrekord, Iran \\ ${ }^{3}$ Department of Microbiology, Faculty of Medical Sciences, Isfahan University of Medical Sciences, Isfahan, Iran
}

Correspondence should be addressed to Hajieh Ghasemian Safaei; ghasemian@med.mui.ac.ir

Received 5 January 2013; Accepted 3 February 2013

Academic Editors: C. Lu and H. Marcotte

Copyright (C) 2013 Ahmad Reza Bahrami et al. This is an open access article distributed under the Creative Commons Attribution License, which permits unrestricted use, distribution, and reproduction in any medium, provided the original work is properly cited.

Helicobacter pylori infection in human is one of the most common infections worldwide. However, the origin and transmission of this bacterium has not been clearly explained. One of the suggested theories is transmission via water. This study was conducted to determine the prevalence rate of $H$. pylori in tap water, dental units' water, and bottled mineral water in Iran. In the present study, totally 200 water samples were collected in Isfahan province and tested for $H$. pylori by cultural method and polymerase chain reaction (PCR) by the detection of the ure $\mathrm{C}(\mathrm{g} \operatorname{lm} M)$ gene. Using cultural method totally 5 cultures were positive. Two out of 50 tap water samples (4\%), 2 out of 35 dental units' water (5.8\%) samples, and 1 out of $40(2.5 \%)$ from water cooler in public places were found to be contaminated with $\mathrm{H}$. pylori. $\mathrm{H}$. pylori ure C gene was detected in 14 (7\%) of water samples including 5 tap water (10\%), 4 dental units' water (11.4\%), 1 refrigerated water with filtration, and 4 (10\%) water cooler in public places samples. This may be due to the coccoid form of bacteria which is detected by PCR method.

\section{Introduction}

Helicobacter pylori is a gram-negative microaerophilic rod found in the human gastric mucosa and is associated with different digestive diseases, such as peptic ulcer, gastritis, and mucosa-associated lymphoid tissue lymphoma [1], and it is considered a risk factor in the development of gastric cancer [2].

H. pylori infection is frequently acquired during childhood, and symptoms such as vomiting and epigastric or recurrent abdominal pain are associated with $H$. pylori infection [3]. In developing countries, it is estimated that $70-90 \%$ of the population carries $H$. pylori, contrasting to $25-50 \%$ of infection among the inhabitants of developed countries [4]. It has been demonstrated that people living in developing countries acquire the infection earlier in life, when compared with individuals of the same age group in developed countries [5].
Despite the high incidence of the infection, the reservoirs and the transmission pathways of $H$. pylori to humans are still unclear, although multiple routes of transmission have been suggested [6]. The current literature suggests that the transmission of $H$. pylori occurs by person to person both via the oral-oral and fecal-oral routes [7]. Furthermore, many authors suggested that the human infection may occur by contaminated foods $[8,9]$. Indeed, $H$. pylori has been detected from drinking water [10-13], sea water [14], and foods of animal origin, such as sheep and cow milk [15-17]. Epidemiological studies have shown that infection with $H$. pylori is associated with the level of sanitation, particularly water sanitation.

This study was conducted to determine the occurrence of $H$. pylori in tap water, dental units' water, water cooler in public places, refrigerated water with filtration, and bottled mineral water in Isfahan provinces, by means of a conventional bacteriological procedures and polymerase chain reaction (PCR). 


\section{Materials and Methods}

2.1. Sample Collection. Isfahan province-with a population of 4,800,000 and area of 291,107,044 square kilometersis the second biggest province of Iran and is located in the central part of Iran among Iran's central mountains eastern hillside of Zagros at the margin of the ZayandeRood River. The drinking water of this province is supplied from the Zayande-Rood River which is considered to be surface water. It is probable that this water is contaminated with industrial and urban sewerage at the margin of this river. Other than refinement, water receives no treatment such as radiation. Taking all this, and given that this river is the only water source for companies producing bottled mineral water in this province, it is likely that one of the sources of microbial contamination in this area is water. In this study, a total of 200 samples including 50 samples of tape water, 35 samples of dental units, 30 samples of home refrigerator with filtration system, 25 samples tape water equipped with filtration system, 40 samples from water cooler in public places, and 20 samples of mineral bottled water were examined over a period of 6 months, from July to December 2011 from four different geographical regions of Isfahan province. For each region, 10-15 samples were collected in $1,000 \mathrm{~mL}$ glass bottles containing $0.5 \mathrm{~g}$ of sodium thiosulphate for dechlorination of the water. The 20 bottled mineral water samples were purchased from five different companies (using the same water system) on the day that the experiment was conducted.

2.2. Isolation of Helicobacter pylori. Samples of $1000 \mathrm{~mL}$ water collected in sterile glass flasks and transferred to laboratory within 2 hours. Samples were filtered through $0.045 \mu \mathrm{m}$ filter membrane (Albet Co.). Each membrane was then immersed into $2 \mathrm{~mL}$ of tryptic soy broth (TSB) for $1 \mathrm{~h}$. After that each $2 \mathrm{~mL}$ TSB was taken and cultured for $H$. pylori and DNA extraction. Samples were cultured on Brucella agar (Merck, Germany) containing campylobacter selective supplement ( $5 \mathrm{mg} / \mathrm{L}$, Merck), trimethoprim $(0.25 \mathrm{mg} / \mathrm{L})$, amphotericin B, sheep blood (5\%), and $7 \%$ fetal calf serum (Sigma). After $72 \mathrm{~h}$ incubation at $37^{\circ} \mathrm{C}$ in microaerophilic condition $(5 \%$ $\mathrm{O}_{2}, 85 \% \mathrm{~N}_{2}, 10 \% \mathrm{CO}_{2}$ ) using MART system (Anoxamat, Lichtenvoorde, The Netherlands), the bacterial growth was tested and confirmed as $H$. pylori by gram staining, urease, and oxidase tests [1]. The isolates were identified as H. pylori were also positive, using the PCR assay. For comparison, a reference strain of $H$. pylori (ATCC 43504) was employed.

2.3. Detection of Helicobacter pylori Using PCR Method. DNA was extracted by a DNA isolation kit from mentioned TSB (Roche Applied Science, Germany) according to the manufacturer's instructions, and its density was assessed by optic densitometry. Extracted genomic DNA was amplified for the ureC $(\operatorname{glm} M)$ gene and detected with the specific primers HP-F: $5^{\prime}$-GAATAAGCTTTTAGGGGTGTTAGGGG-3' and HP-R: 5'-AAGCTTACTTTCTAACACTAACGCGC- ${ }^{\prime}$. The gene product was $294 \mathrm{bp}$. PCR reactions were performed in a final volume of $50 \mu \mathrm{L}$ containing $5 \mu \mathrm{L} 10 \times$ buffer $+\mathrm{MgCl}_{2}$,
$2 \mathrm{mM}$ dNTP, 2 unit Taq DNA polymerase, $100 \mathrm{ng}$ genomic DNA as a template, and 25 picomoles of each primer. PCR was performed using a thermal cycler (Eppendorf Co., Germany) under the following conditions: an initial denaturation for 10 minutes at $94^{\circ} \mathrm{C}$; and 35 cycles for 1 minute at $94^{\circ} \mathrm{C}, 1$ minute at $55^{\circ} \mathrm{C}, 1$ minute at $72^{\circ} \mathrm{C}$, and a final extension at $72^{\circ} \mathrm{C}$ for 10 minutes. The PCR products were electrophoresed through a $1.5 \%$ agarose gels (Fermentas, Germany) containing Ethidium bromide. A DNA ladder (Fermentas Co., Germany) was used to detect the molecular weight of observed bands under a UV lamp. All tests were performed in triplicate. Samples inoculated with $H$. pylori were used as positive controls.

2.4. Statistical Analysis. Data were transferred to Microsoft Excel spreadsheet (Microsoft Corp., Redmond, WA, USA) for analysis. Using SPSS 16.0 statistical software (SPSS Inc., Chicago, IL, USA), Chi-square test and Fisher's exact twotailed test analysis was performed, and differences were considered significant at values of $P<0.05$.

\section{Results and Discussion}

Using traditional bacteriologic methods, totally 5 cultures were positive. Two of 50 tap water samples (4\%), 2 out of 35 dental units' water (5.8\%) samples, and 1 of 40 (2.5\%) from water cooler in public places were found to be contaminated with $H$. pylori. $H$. pylori ureC gene was detected in $14(7 \%)$ of water samples including 5 tap water (10\%), 4 dental units' water $(11.4 \%)$, and $4(10 \%)$ water cooler in public places samples (Table 1). Statistically significant differences $(P>$ 0.05) were not observed in the prevalence of $H$. pylori ure C gene in water samples collected from different geographical regions of Isfahan province.

The association of serum antibodies against $H$. pylori with serum antibodies against two known waterborne pathogens hepatitis A virus [18] and Giardia [19] suggests that the infection may be waterborne or related to poor sanitary practices [20]. Klein et al. [21] studied the prevalence of $H$. pylori infection in 407 children (two months to 12 years old), in Lima, Peru. H. pylori infection rate was $56 \%$ among children from low-income families and 32\% among those from high-income families. However, children from highincome families whose homes were supplied with municipal water were 12 times more likely to be infected than those from the same socioeconomic status whose water supply came from community wells. These results showed that the acquisition of $H$. pylori infection by Peruvian children was correlated with socioeconomic status, but additionally the municipal water supply seemed to be involved in the spread of infection among them. Indirect evidence that the transmission of $H$. pylori is waterborne is based upon four sets of data: (i) presence of DNA in water samples, (ii) observation of coccoid forms in water samples, (iii) survival of $H$. pylori in artificially contaminated water, and (iv) growth of $H$. pylori from water samples [20].

In the present study, only two tap water samples (4\%) were found to be contaminated with $H$. pylori using traditional bacteriologic methods. H. pylori has rarely been 
TABLE 1: Frequency of Helicobacter pylori detected in different water samples in Iran by PCR.

\begin{tabular}{lccc}
\hline Water sample & No. of samples & No. of $H$. pylori-positive by culture* & No. of H. pylori-positive by PCR \\
\hline Tap water & 50 & $2(4.0 \%)$ & $5(10.0 \%)$ \\
Dental units' water & 35 & $2(5.8 \%)$ & $4(11.4 \%)$ \\
Bottled mineral water & 20 & 0 & 0 \\
Refrigerated water with filtration & 30 & 0 & $1(3.3 \%)$ \\
Tape water equipped with filtration system & 25 & 0 & 0 \\
Water cooler in public places & 40 & $1(2.5 \%)$ & $4(10.0 \%)$ \\
\hline Total & 200 & $5(2.5 \%)$ & $14(7.0 \%)$
\end{tabular}

* Results expressed as the number of $H$. pylori-positive samples (percent positive samples analyzed).

isolated from water samples $[22,23]$. In several studies no $H$. pylori was found in water samples $[8,24,25]$. This could be attributed to the fact that $H$. pylori can survive for short period of time in water $[8,20]$. Moreover, the method employed for $H$. pylori isolation may lack sufficient sensitivity to recover very low numbers of $H$. pylori $[2,23,26,27]$.

Two out of 35 dental units' water samples were found to be contaminated with $H$. pylori using traditional bacteriologic methods. The presence of $H$. pylori associated with biofilms from wells, rivers, and water distribution systems has been reported by different investigators [28-32]. Biofilms are slimy films of bacteria, other microbes, and organic materials that cover underwater surfaces, particularly inside plumbing. This makes them rather inaccessible and provides a matrix difficult to be reached by disinfectants. The detachment of biofilms is the principal form of contamination of treated water $[33,34]$. Taken together, these results suggest that biofilms in water distribution systems are responsible for the contamination of water.

In this study, ure $C$ gene of $H$. pylori was detected in tap water, dental units' water, refrigerated water with filtration, and public cooler water samples. H. pylori DNA has been identified in several water sources using diverse gene targets. Drinking, river, sea, ground, and wastewater have provided positive results by PCR analysis [9, 14, 23, 24, 35-37]. The $H$. pylori DNA present in water samples could be from dead $H$. pylori cells or from VBNC forms, since culture is usually not possible. Water spiked with viable $H$. pylori cells rapidly led to the observation of coccoid forms $[23,27,38,39]$. Whether the coccoid form of $H$. pylori is viable in the dormant state or is degenerative and undergoing apoptosis is still an unanswered question. Coccoid $H$. pylori appears to conserve the capacity to produce proteins for at least 100 days when stored at $4^{\circ} \mathrm{C}$, in either phosphate-buffered saline (PBS) or distilled water [40]. It has been suggested that although the virulence of coccoid $H$. pylori induced by water decreases, the coccoid forms still retain a considerable urease activity and preserve adhering ability to epithelial cells. These coccoid forms induced by water have been capable of colonizing the gastric mucosa, causing gastritis in mice [41].

The PCR assay employed in this work specifically targets a region of the $\operatorname{ureC}(\mathrm{glm} M)$ gene which has been shown to be unique and essential for the growth of $H$. pylori. It has been previously reported that detecting this gene improves sensitivity and specificity of recognition of $H$. pylori in samples containing prokaryotic cells as well as many organic impurities $[9,17,37]$. However, because the PCR assay detects ure $C(g \operatorname{lm} M)$ gene of $H$. pylori, we are unable to speculate on the viability of organisms in water samples.

The high prevalence of $H$. pylori isolated from healthy human carrier $[42,43]$ suggests that water contamination is due to poor hygiene management. Therefore, the consumption of tap water and dental units' water would be a potential risk of $H$. pylori infection for the consumer. To the author's knowledge, the present study is the first report of the isolation of $H$. pylori from water in Iran and the first demonstration of H. pylori DNA in tap water, dental units' water, refrigerated water with filtration, and public water cooler samples. Further studies will be necessary to determine the prevalence of H. pylori in water and other foods in Iran and to explore the potential risk of human infection with $H$. pylori via consumption of water and foods.

\section{Acknowledgment}

This work was supported by Vice Chancellor of Research of Isfahan University of Medical Sciences, Isfahan, Iran.

\section{References}

[1] B. E. Dunn, H. Cohen, and M. J. Blaser, "Helicobacter pylori", Clinical Microbiology Reviews, vol. 10, no. 4, pp. 720-741, 1997.

[2] World Health Organization, "Infection with Helicobacter pylori," IARC Monographs on the Evaluation of Carcinogenic Risks To Humans, vol. 61, pp. 177-240, 1994.

[3] B. Drumm, S. Koletzko, and G. Oderda, "Helicobacter pylori infection in children: a consensus statement," Journal of Pediatric Gastroenterology and Nutrition, vol. 30, no. 2, pp. 207-213, 2000.

[4] L. M. Brown, "Helicobacter pylori: epidemiology and routes of transmission," Epidemiologic Reviews, vol. 22, no. 2, pp. 283-297, 2000.

[5] A. Lee, "The microbiology and epidemiology of Helicobacter pylori infection," Scandinavian Journal of Gastroenterology, vol. 29, no. S201, pp. 2-6, 1994.

[6] R. P. Allaker, K. A. Young, J. M. Hardie, P. Domizio, and N. J. Meadows, "Prevalence of Helicobacter pylori at oral and gastrointestinal sites in children: evidence for possible oral-tooral transmission," Journal of Medical Microbiology, vol. 51, no. 4, pp. 312-317, 2002. 
[7] L. Cellini, L. Marzio, G. Ferrero et al., "Transmission of Helicobacter pylori in an animal model," Digestive Diseases and Sciences, vol. 46, no. 1, pp. 62-68, 2001.

[8] B. C. Gomes and E. C. P. De Martinis, "The significance of Helicobacter pylori in water, food and environmental samples," Food Control, vol. 15, no. 5, pp. 397-403, 2004.

[9] N. C. Quaglia, A. Dambrosio, G. Normanno et al., "High occurrence of Helicobacter pylori in raw goat, sheep and cow milk inferred by glmM gene: a risk of food-borne infection?" International Journal of Food Microbiology, vol. 124, no. 1, pp. 43-47, 2008.

[10] M. K. Glynn, C. R. Friedman, B. D. Gold et al., "Seroincidence of Helicobacter pylori infection in a cohort of rural Bolivian children: acquisition and analysis of possible risk factors," Clinical Infectious Diseases, vol. 35, no. 9, pp. 1059-1065, 2002.

[11] J. P. Hegarty, M. T. Dowd, and K. H. Baker, "Occurrence of Helicobacter pylori in surface water in the United States," Journal of Applied Microbiology, vol. 87, no. 5, pp. 697-701, 1999.

[12] Y. Lu, T. E. Redlinger, R. Avitia, A. Galindo, and K. Goodman, "Isolation and genotyping of Helicobacter pylori from untreated municipal wastewater," Applied and Environmental Microbiology, vol. 68, no. 3, pp. 1436-1439, 2002.

[13] N. Queralt, R. Bartolomé, and R. Araujo, "Detection of Helicobacter pylori DNA in human faeces and water with different levels of faecal pollution in the north-east of Spain," Journal of Applied Microbiology, vol. 98, no. 4, pp. 889-895, 2005.

[14] L. Cellini, A. Del Vecchio, M. Di Candia, E. Di Campli, M. Favaro, and G. Donelli, "Detection of free and planktonassociated Helicobacter pylori in seawater," Journal of Applied Microbiology, vol. 97, no. 2, pp. 285-292, 2004.

[15] M. P. Dore, A. R. Sepulveda, and H. El-Zimaty, "Isolation of Helicobacter pylori from milk sheep-implications for transmission to humans," American Journal of Gastroenterology, vol. 96, pp. 1396-1401, 2001.

[16] S. Fujimura, T. Kawamura, S. Kato, H. Tateno, and A. Watanabe, "Detection of Helicobacter pylori in cow's milk," Letters in Applied Microbiology, vol. 35, no. 6, pp. 504-507, 2002.

[17] H. G. Safaei, E. Rahimi, A. Zandi, and A. Rashidipour, "Helicobacter pylori as a zoonotic infection: the detection of $H$. pylori antigens in the milk and faeces of cows," Journal of Research in Medical Sciences, vol. 16, no. 2, pp. 184-187, 2011.

[18] A. R. Bizri, I. A. Nuwayhid, G. N. Hamadeh, S. W. Steitieh, A. M. Choukair, and U. M. Musharrafieh, "Association between hepatitis A virus and Helicobacter pylori in a developing country: the saga continues," Journal of Gastroenterology and Hematology, vol. 21, no. 10, pp. 1615-1621, 2006.

[19] E. D. Moreira, V. B. Nassri, R. S. Santos et al., "Association of Helicobacter pylori infection and giardiasis: results from a study of surrogate markers for fecal exposure among children," World Journal of Gastroenterology, vol. 11, no. 18, pp. 2759-2763, 2005.

[20] F. F. Vale and J. M. B. Vítor, "Transmission pathway of Helicobacter pylori: does food play a role in rural and urban areas?" International Journal of Food Microbiology, vol. 138, no. 1-2, pp. $1-12,2010$.

[21] P. D. Klein, R. Gilman, R. Leon-Barua et al., "Water source as risk factor for Helicobacter pylori infection in Peruvian children," The Lancet, vol. 337, no. 8756, pp. 1503-1506, 1991.

[22] N. F. Azevedo, C. Almeida, I. Fernandes et al., "Survival of gastric and enterohepatic Helicobacter spp. in water: Implications for transmission," Applied and Environmental Microbiology, vol. 74, no. 6, pp. 1805-1811, 2008.
[23] N. Queralt and R. Araujo, "Analysis of the survival of $H$. pylori within a laboratory-based aquatic model system using molecular and classical techniques," Microbial Ecology, vol. 54, no. 4, pp. 771-777, 2007.

[24] K. Hulten, S. W. Han, H. Enroth et al., "Helicobacter pylori in the drinking water in Peru," Gastroenterology, vol. 110, no. 4, pp. 1031-1035, 1996.

[25] S. L. Percival and J. G. Thomas, "Transmission of Helicobacter pylori and the role of water and biofilms," Journal of Water and Health, vol. 7, no. 3, pp. 469-477, 2009.

[26] A. S. Angelidis, I. Tirodimos, and M. Bobos, "Detection of Helicobacter pylori in raw bovine milk by fluorescence in situ hybridization (FISH)," International Journal of Food Microbiology, vol. 151, no. 2, pp. 252-256, 2011.

[27] Y. Moreno, P. Piqueres, J. L. Alonso, A. Jimenez, A. Gonzalez, and M. A. Ferrus, "Survival and viability of Helicobacter pylori after inoculation into chlorinated drinking water," Water Research, vol. 41, no. 15, pp. 3490-3496, 2007.

[28] J. E. G. Bunn, W. G. MacKay, J. E. Thomas, D. C. Reid, and L. T. Weaver, "Detection of Helicobacter pylori DNA in drinking water biofilms: implications for transmission in early life," Letters in Applied Microbiology, vol. 34, no. 6, pp. 450-454, 2002.

[29] S. M. Bragança, N. F. Azevedo, L. C. Simöes, C. W. Keevil, and M. J. Vieira, "Use of fluorescent in situ hybridisation for the visualisation of Helicobacter pylori in real drinking water biofilms," Water Science and Technology, vol. 55, no. 8-9, pp. 387393, 2007.

[30] M. S. Giao, N. F. Azevedo, S. A. Wilks, M. J. Vieira, and C. W. Keevil, "Persistence of Helicobacter pylori in heterotrophic drinking-water biofilms," Applied and Environmental Microbiology, vol. 74, no. 19, pp. 5898-5904, 2008.

[31] S. R. Park, W. G. Mackay, and D. C. Reid, "Helicobacter sp. recovered from drinking water biofilm sampled from a water distribution system," Water Research, vol. 35, no. 6, pp. 16241626, 2001.

[32] C. L. Watson, R. J. Owen, B. Said et al., "Detection of Helicobacter pylori by PCR but not culture in water and biofilm samples from drinking water distribution systems in England," Journal of Applied Microbiology, vol. 97, no. 4, pp. 690-698, 2004.

[33] M. Gouider, J. Bouzid, S. Sayadi, and A. Montiel, "Impact of orthophosphate addition on biofilm development in drinking water distribution systems," Journal of Hazardous Materials, vol. 167, no. 1-3, pp. 1198-1202, 2009.

[34] P. Stoodley, S. Wilson, L. Hall-Stoodley, J. D. Boyle, H. M. Lappin-Scott, and J. W. Costerton, "Growth and detachment of cell clusters from mature mixed-species biofilms," Applied and Environmental Microbiology, vol. 67, no. 12, pp. 5608-5613, 2001.

[35] T. Horiuchi, T. Ohkusa, M. Watanabe, D. Kobayashi, H. Miwa, and Y. Eishi, "Helicobacter pylori DNA in drinking water in Japan," Microbiology and Immunology, vol. 45, no. 7, pp. 515-519, 2001.

[36] M. Mazari-Hiriart, Y. López-Vidal, and J. J. Calva, "Helicobacter pylori in water systems for human use in Mexico City," Water Science and Technology, vol. 43, no. 12, pp. 93-98, 2001.

[37] N. C. Quaglia, A. Dambrosio, G. Normanno, and G. V. Celano, "Evaluation of a Nested-PCR assay based on the phosphoglucosamine mutase gene (glmM) for the detection of Helicobacter pylori from raw milk," Food Control, vol. 20, no. 2, pp. 119-123, 2009.

[38] B. L. Adams, T. C. Bates, and J. D. Oliver, "Survival of Helicobacter pylori in a natural fresh water environment," Applied 
and Environmental Microbiology, vol. 69, no. 12, pp. 7462-7466, 2003.

[39] A. K. Nayak and J. B. Rose, "Detection of Helicobacter pylori in sewage and water using a new quantitative PCR method with SYBR green," Journal of Applied Microbiology, vol. 103, no. 5, pp. 1931-1941, 2007.

[40] K. Mizoguchi, S. D. Meyers, S. Basu, and J. J. O’Brien, “Multiand quasidecadal variations of sea surface temperature in the North Atlantic," Journal of Physical Oceanography, vol. 29, no. 12, pp. 3133-3144, 1999.

[41] F. F. She, J. Y. Lin, J. Y. Liu, C. Huang, and D. H. Su, "Virulence of water-induced coccoid Helicobacter pylori and its experimental infection in mice," World Journal of Gastroenterology, vol. 9, no. 3, pp. 516-520, 2003.

[42] G. I. Perez-Perez, D. Rothenbacher, and H. Brenner, "Epidemiology of Helicobacter pylori infection," Helicobacter, vol. 9, supplement 1, pp. 1-6, 2004.

[43] D. Olivares and J. P. Gisbert, "Factors involved in the pathogenesis of Helicobacter pylori infection," Revista Espanola de Enfermedades Digestivas, vol. 98, no. 5, pp. 374-386, 2006. 

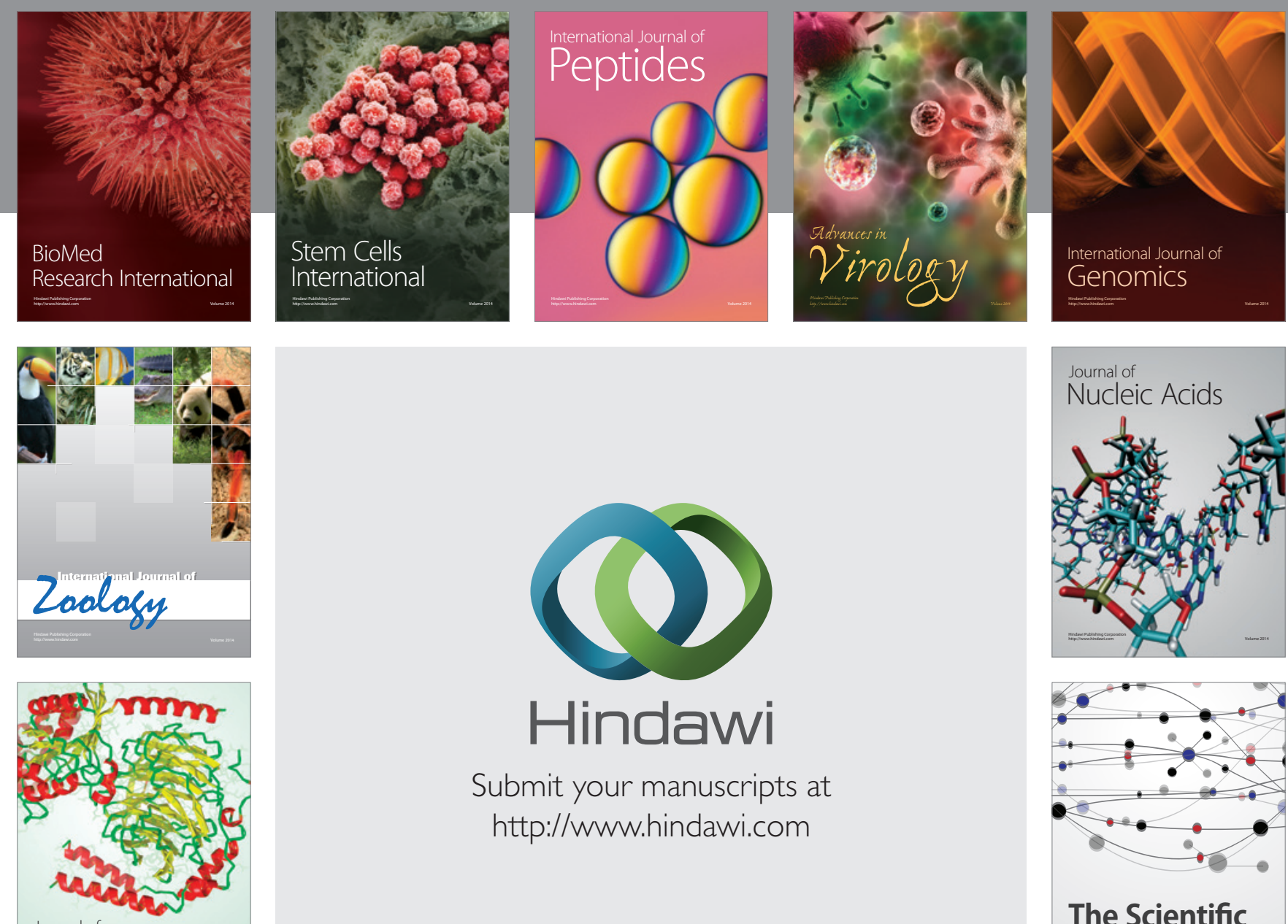

Submit your manuscripts at

http://www.hindawi.com

Journal of
Signal Transduction
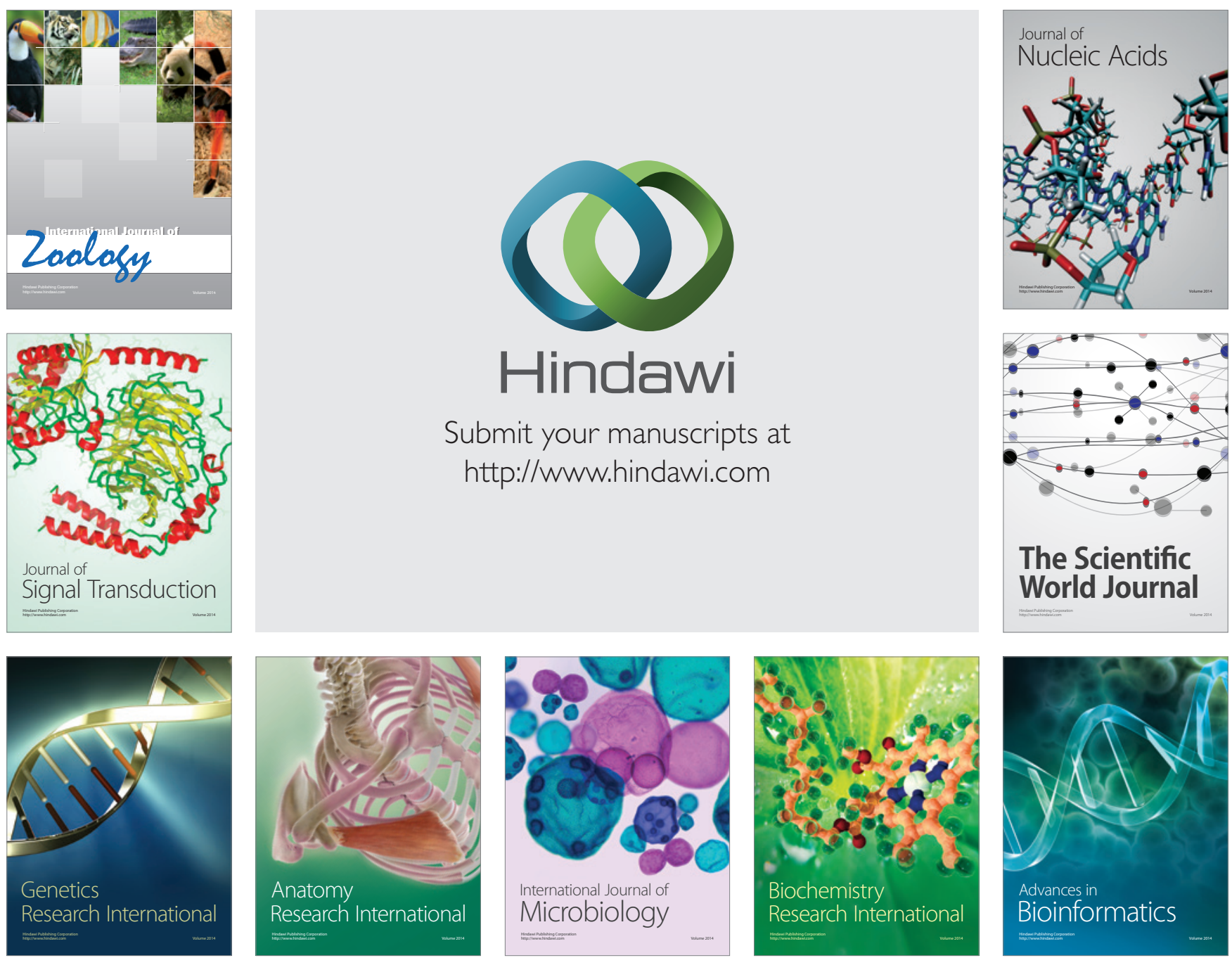

The Scientific World Journal
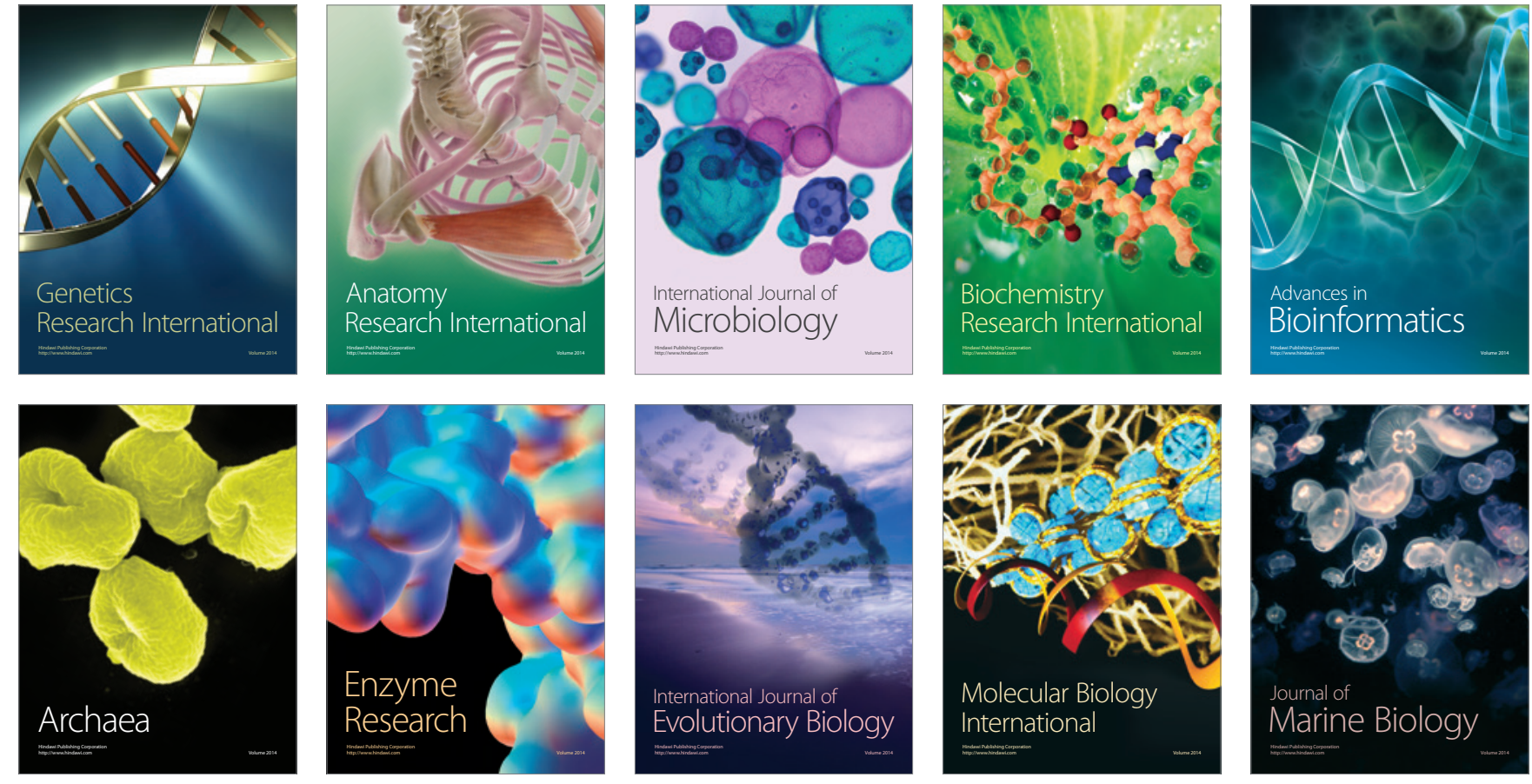